\title{
Levels of shading and application of glyphosate and carfentrazone-ethyl in the control of Macroptilium atropurpureum
}

\author{
Gustavo A. Costa ${ }^{1}$, Leonardo D. T. Santos ${ }^{1}$, Guilherme A. de P. Ferreira ${ }^{1}$, \\ Leandro R. da Cruz ${ }^{2}$, Vitor D. Machado ${ }^{3}$ \& Leonardo M. Rocha ${ }^{1}$
}

${ }^{1}$ Universidade Federal de Minas Gerais/Instituto de Ciências Agrárias. Montes Claros, MG. E-mail: gustavoac88@hotmail.com - ORCID: 0000-0002-9300-5518; ltuffi@ufmg.br - ORCID:0000-0002-9362-778X; guilhermepaiva017@gmail.com - ORCID: 0000-0001-6266-9963; leonardorocha.agronomia@gmail.com - ORCID: 0000-0003-2955-5619

${ }^{2}$ Universidade Estadual Paulista Júlio de Mesquita Filho/Faculdade de Ciências Agronômicas/Departamento de Melhoramento e Produção Vegetal. Botucatu, SP. E-mail: leandrocruz2001@yahoo.com.br - ORCID: 0000-0002-5673-6506

${ }^{3}$ Universidade Federal de Minas Gerais. Montes Claros, MG. E-mail: vdinizmachado@yahoo.com.br (Corresponding author) - ORCID: 0000-0002-1730-4567

\section{Key words:}

physiology

siratro

photosynthetic rate

leaf area

\begin{abstract}
A B S T R A C T
Variations in environmental conditions, such as the availability of light, can affect the efficacy of herbicides because they alter the biological characteristics of plants including those that are related to the plant's sensitivity to herbicides. Therefore, the objective of the present study was to assess the influence of environments with different light availabilities, and of the application of glyphosate and carfentrazone-ethyl (separately or in combination) on the morphophysiology and control of Macroptilium atropurpureum. An experimental design of randomized blocks with five replicates was used, with treatments arranged in a split-plot design. The plots were composed of three levels of shading (full sunlight, $50 \%$ shading, and $70 \%$ shading); within each plot there were sub-plots, one for each of the two herbicides (glyphosate and carfentrazone-ethyl), used either separately or in combination. The doses of glyphosate + carfentrazone-ethyl applied in the treatments were $0+40 \mathrm{~g} \mathrm{ha}^{-1}$ of carfentrazoneethyl, $1.440+0 \mathrm{~g} \mathrm{ha}^{-1}$ of glyphosate, $1.080+30 \mathrm{~g} \mathrm{ha}^{-1}$ of glyphosate + carfentrazone-ethyl, and there was an additional treatment that did not include the application of an herbicide. Plants of M. atropurpureum cultivated under shading exhibited higher sensitivity to the herbicides, greater leaflet area, and lower photosynthetic rates than plants cultivated under full sunlight conditions. Under shading, both herbicides applied separately or in combination were effective in controlling $M$. atropurpureum, which indicates a greater susceptibility of this species to these herbicides in environments with light restriction. The species was tolerant to the two tested herbicides, used either alone or in combination, when grown under full sunlight conditions.
\end{abstract}

\section{Palavras-chave:}

fisiologia

siratro

taxa fotossintética

área foliar

\section{Níveis de sombreamento e aplicação de glifosato e carfentrazone-etil no controle de Macroptilium atropurpureum}

\section{R E S U M O}

Variações nas condições ambientais, como a disponibilidade luminosa, podem afetar a eficiência de controle dos herbicidas por alterar características biológicas das plantas relacionadas à sensibilidade aos herbicidas. Desse modo, objetivou-se avaliar a influência do cultivo em ambientes com diferentes disponibilidades luminosas e da aplicação isolada ou em mistura de glifosato e carfentrazone-etil, sobre a morfofisiologia e o controle de $M$. atropurpureum. O delineamento adotado foi o de blocos casualizados, em esquema de parcelas subdivididas com 5 repetições. As parcelas foram constituídas de três níveis de sombreamento (pleno sol, 50 e $70 \%$ de sombra) e as subparcelas de dois herbicidas (glifosato e carfentrazoneetil) combinados ou não. As doses de glifosato + carfentrazone-etil utilizadas foram $0+40 \mathrm{~g} \mathrm{ha}^{-1}$ de carfentrazone-etil, 1,440+0 $\mathrm{g} \mathrm{ha}^{-1}$ de glifosato, 1,080+30 $\mathrm{g} \mathrm{ha}^{-1}$ de glifosato + carfentrazoneetil e mais um tratamento sem aplicação de herbicida. Plantas de $M$. atropurpureum cultivadas sob sombreamento apresentaram maior sensibilidade aos herbicidas, maior área dos folíolos e menor taxa fotossintética em comparação ao seu cultivo em ambiente a pleno sol. Em sombreamento, tanto os herbicidas aplicados isoladamente quanto a mistura são efetivos no controle do $M$. atropurpureum, o que indica maior susceptibilidade dessa espécie aos herbicidas em ambientes com restrição luminosa. A espécie é tolerante aos dois herbicidas testados, isolados ou em mistura, quando crescida a pleno sol. 


\section{INTRODUCTION}

Macroptilium atropurpureum is a legume that occurs naturally in several tropical regions that are difficult to grow in, owing to their certain characteristics, such as low fertility requirements and tolerance to both water stress and poorly drained soils (Skerman, 1977; Santos et al., 2000). It is a plant with forage potential but also considered a weed, being characterized by a high capacity for seed production, tolerance to stress conditions, and a variable growth habit (Lorenzi, 2008).

In addition to the intrinsic characteristics of M. atropurpureum, it is also important to consider the interference of the crop environment with the management of the species, including its sensitivity to herbicides. Abiotic factors are modified by the crop environment as a result of the microclimate created by the crop canopy. These environmental conditions promote modifications in the anatomy, morphology, and physiology of weeds, which influences the interception, absorption, translocation, and detoxification of herbicides in the plants (Cieslik et al., 2013; Santos Júnior et al., 2013; Matzenbacher et al., 2014; Kucharski \& Kieloch, 2015; Bagavathiannan et al., 2017).

Environmental conditions resulting from the frequent use of the same herbicide can favor the selection of individuals that are tolerant and/or resistant to one or more mechanisms of action of the herbicide (Santos et al., 2013; 2015), or of plants that are better adapted to specific environmental conditions. Combining herbicides with different and synergistic mechanisms of action is an interesting strategy for increasing the spectrum of action and efficiency of chemical control (Braz et al., 2013).

The action of herbicides on plants grown under shade is quite variable, depending on the mechanism of action of the herbicide and on the response of the weed species to radiation restriction (Fonseca et al., 2016; Besançon et al., 2017). Thus, knowledge about the effect of herbicides with distinct mechanisms of action in plants established in environments with different levels of insolation is essential to develop improved management strategies.

Research on the biology of $M$. atropurpureum and its responses to chemical control are scarce in the literature, especially in terms of data obtained from distinct growth environments. Therefore, the objective of the present study was to assess the effect of environments with different light availabilities and of the application of glyphosate and carfentrazone-ethyl (separately or in combination) on the morphophysiological characteristics and control of cultivated M. atropurpureum.

\section{Material ANd Methods}

The experiment was conducted between February and May 2014 in Montes Claros, MG, Brazil (43 50' 18.31' W, 16 ${ }^{\circ} 40^{\prime}$ $59.22^{\prime \prime}$, altitude of $\left.650 \mathrm{~m}\right)$. The climate of the region is tropical with wet winters (As), according to the Köppen classification (Alvares et al., 2014). Figure 1 shows climatic data during the experimental period.

Seedlings of $M$. atropurpureum were initially produced by seminiferous propagation in Styrofoam trays filled with

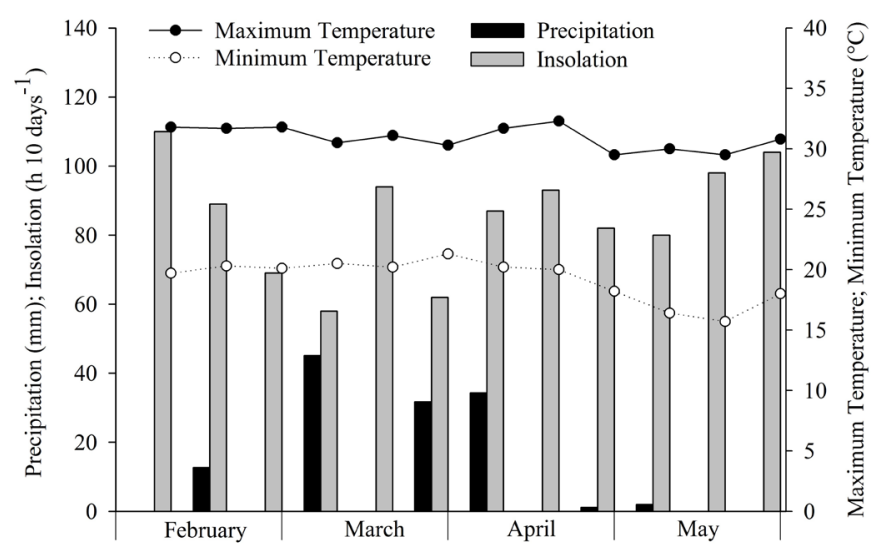

Figure 1. Ten-day means of insolation $\left(\mathrm{h} \mathrm{day}^{-1}\right)$, precipitation $(\mathrm{mm})$, and minimum and maximum temperatures $\left({ }^{\circ} \mathrm{C}\right)$ relative to the period from February to May of 2014, Montes Claros, Minas Gerais

commercial substrate. The seeds that were used were collected from naturally-grown plants present in a commercial orange grove. Thirty days after planting, two plants were transferred to $12 \mathrm{dm}^{3}$ pots containing substrate consisting of sandy soil plus fertilizers. These plants were selected to obtain a standardized number of plant leaves and height. The soil used in the experiment was collected in a way so as to avoid removing the superficial layer so that contamination by weeds did not occur; the chemical characteristics of the collected soil were as follows: $\mathrm{pH}$ (water): 4.7; organic matter content: $2.37 \mathrm{dag} \mathrm{kg}^{-1}$; P: $0.47 \mathrm{mg} \mathrm{dm}^{-3}$; K: $35 \mathrm{mg} \mathrm{dm}^{-3}$; Ca: $0.20 \mathrm{cmol}_{\mathrm{c}} \mathrm{dm}^{-3}$; $\mathrm{Mg}^{-3}$ $0.10 \mathrm{cmol}_{\mathrm{c}} \mathrm{dm}^{-3}$; Al: $0.60 \mathrm{cmol} \mathrm{dm}_{\mathrm{c}}^{-3}$; H+Al: $2.90 \mathrm{cmol} \mathrm{dm}_{c}^{-3}$; ECEC: $0.99 \mathrm{cmol} \mathrm{dm}^{-3}$; BS: $11.84 \%$. The substrate was fertilized with single superphosphate, potassium chloride, and urea, according to the recommendations of Cantarutti et al. (2007). Soil moisture content was maintained near field levels through irrigation performed twice a day.

An experimental design of randomized blocks with five replicates was used. The treatments were arranged in a split-plot design, in which the levels of shading $(0,50$, or $70 \%$ of shade) were allocated to the plots and the herbicide treatments (applied separately or in combination), i.e., $40 \mathrm{~g} \mathrm{ha}^{-1}$ of carfentrazoneethyl, $1.080+30 \mathrm{~g} \mathrm{ha}^{-1}$ of glyphosate + carfentrazone-ethyl, and $1.440 \mathrm{~g} \mathrm{ha}^{-1}$ of glyphosate and the treatments without herbicide were allocated to the sub-plots.

The environments providing shade had $50 \pm 4.2 \%$ $\left(1.560 \mu \mathrm{mol} \mathrm{m} \mathrm{m}^{-2}\right)$ and $70 \pm 3.8 \%\left(890 \mu \mathrm{mol} \mathrm{m} \mathrm{s}^{-2}\right)$ of light interception, which was achieved by using black polypropylene shade screens (sombrite) with light interception corresponding to 50 and $70 \%$, as per the manufacturer's specifications. Light interception was measured at noon, with 10 spot measurements in each environment, using a linear ceptometer (AccuPAR Linear PAR/LAI ceptometer, Model LP 80; Decagon Devices).

Forty-five days after transplanting, when more than $50 \%$ of the plants were starting to bud, the herbicides were applied using a backpack sprayer equipped with a wand with a TeeJet AI110015 nozzle and a regulating valve to maintain a constant pressure at $150 \mathrm{kPa}$, with the volume of applied herbicide solution being $100 \mathrm{~L} \mathrm{ha}^{-1}$. The applications were performed in the morning to avoid high temperatures.

Photosynthetic rates (A) were assessed between the first and third completely expanded leaves in the upper third of the 
plants, two and six days after herbicide application (DAA). The evaluation period was determined based on the time required for the stress caused by the herbicides to manifest in the plants, while the plants were still fit to be assessed. A portable infrared gas analyzer (IRGA) (model LCA 4, Analytical Development Co. Ltd, Hoddesdon, UK) was used. It measured leaf gas exchange based on $\mathrm{CO}_{2}$ variations and relative humidity inside the device's chamber.

The dry biomass of the aerial part of the plants was determined 28 DAA by collecting all the living plant materials that remained in the pot and transferring it to a forced air circulation oven at $55{ }^{\circ} \mathrm{C}$ until a constant weight was reached. The mean leaflet area was determined by collecting the completely expanded leaves of the upper third part of the plants in the treatments without herbicide application in each crop environment. These were scanned and subjected to image analysis using the ImagePro Plus software, version 4.1, for Windows ${ }^{\oplus}$ (Media Cybernetics, Silver Spring, MD, USA).

Visual assessments were performed at 28 DAA to evaluate weed control, using a scale of 0 to $100 \%$, where $0 \%$ is the absence of toxic effects caused by the herbicide and $100 \%$ is the total death of plant tissues, according to the method of ALAM (1974).

The data on weed control and leaflet area were analyzed descriptively using means and standard errors. The data on the remaining variables were subjected to analysis of variance by the $\mathrm{F}$ test, and when the result was significant the means were compared by Tukey's test at 5\% probability, using the Proc Mixed procedure of the SAS statistical package (SAS Institute, 2002).

\section{Results AND Discussion}

The application of glyphosate separately or in combination with carfentrazone-ethyl was more effective in the control of $M$. atropurpureum cultivated under shading. Under full sunlight conditions, the mixture provided greater control than the herbicides applied separately; however, the control was unsatisfactory for the effective management of this weed. Under these conditions, the plants were more tolerant to the herbicides (Figure 2). Weed control with the use of one herbicide alone under full sunlight conditions was less than $35 \%$, thus indicating that the species tolerates the tested herbicides.

Under shade, weed control was greater than $90 \%$, i.e. very good, when glyphosate was applied alone or in combination with carfentrazone-ethyl, and there was no additive effect of the herbicide mixture (Figure 2). The control of $M$. atropurpureum was poor when carfentrazone-ethyl was applied separately, regardless of the environment (Figure 2).

The interaction of the herbicides with the crop environment affected the dry mass of the aerial part of $M$. atropurpureum (p $<0.0001)$. The herbicides were more effective in reducing the aerial part when the plants were cultivated in environments with restricted light, regardless of the level of shading (Table 1).

The poor control of $M$. atropurpureum observed with the application of glyphosate and carfentrazone-ethyl, separately or in combination, in an environment under full sunlight

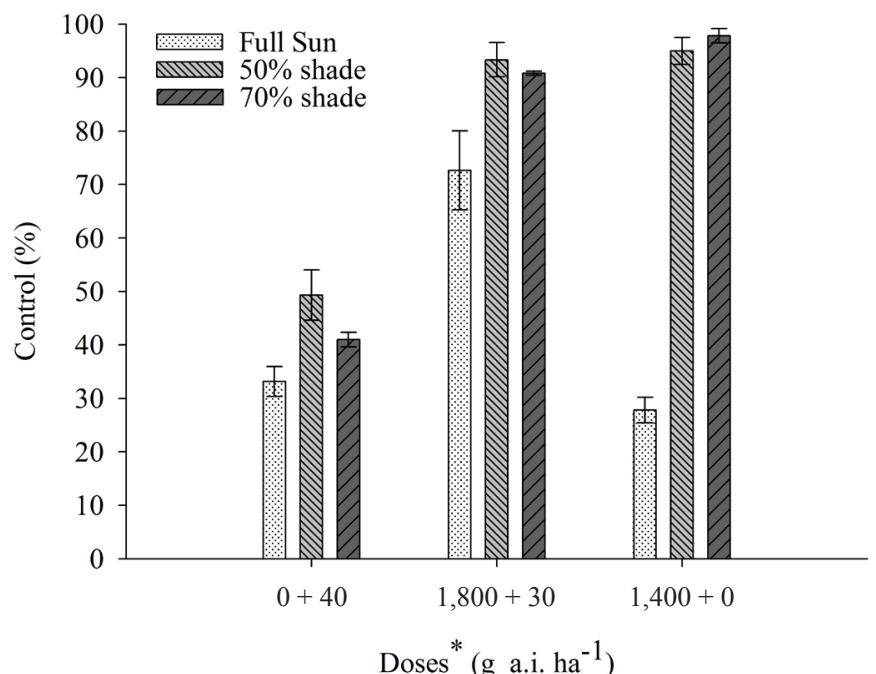

* Doses of glyphosate + carfentrazone-ethyl $\left(0+40 \mathrm{~g} \mathrm{ha}^{-1}\right.$ of carfentrazone-ethyl; $1.440+$ $0 \mathrm{~g} \mathrm{ha}^{-1}$ of glyphosate; and $1.080+30 \mathrm{~g} \mathrm{ha}^{-1}$ of glyphosate + carfentrazone-ethyl)

Figure 2. Control of Macroptilium atropurpureum at 28 days after herbicide application

Table 1. Dry mass of the aerial part (g per pot) of Macroptilium atropurpureum treated with doses of glyphosate and/or carfentrazone-ethyl, depending on the growth environment, at 28 days after herbicide application

\begin{tabular}{ccccc}
\hline \multirow{2}{*}{ Environment } & \multicolumn{3}{c}{ Doses of Glyphosate + Carfentrazone -ethyl ( $\mathbf{g}$ a.i. ha $\mathbf{~}^{-1}$ ) } \\
\cline { 2 - 5 } Full sunlight & $\mathbf{0}+\mathbf{0}$ & $\mathbf{0}+\mathbf{4 0}$ & $\mathbf{1 . 4 4 0 + 0}$ & $\mathbf{1 . 0 8 0}+\mathbf{3 0}$ \\
$50 \%$ shading & $24.46 \mathrm{Ba}$ & $30.85 \mathrm{Aa}$ & $21.94 \mathrm{Ab}$ & $12.95 \mathrm{Ac}$ \\
$70 \%$ shading & $19.55 \mathrm{Ba}$ & $13.11 \mathrm{Bb}$ & $4.84 \mathrm{Bb}$ & $5.95 \mathrm{Bb}$ \\
\multicolumn{5}{c}{$\mathrm{CV}(\%): 20.8$} \\
\hline
\end{tabular}

Means followed by the same letters, uppercase in the column and lowercase in the line, do not differ by Tukey's test at 0.05 probability

conditions (Figure 2) translated into a greater accumulation of plant dry mass (Table 1). The application of carfentrazoneethyl separately under full sunlight conditions did not lead to a reduction in the accumulated biomass of $M$. atropurpureum, in contrast to the results from when the plants were kept under shading, regardless of the level of shading (Table 1). The application of glyphosate, alone or in combination, caused a reduction in the biomass of $M$. atropurpureum relative to the control plants in the crop environments. The mobility of the herbicide carfentrazone-ethyl in the plant is reduced, and, for effective weed control to occur, the applied herbicide must cover a major part of the leaf area. Sometimes, however, the solution only reaches the upper part of the canopy, causing the so-called "umbrella" effect, in which the upper leaves receive the largest volume of herbicide and the lower leaves remain protected (Rocha et al., 2007).

The additive effect provided by the glyphosate + carfentrazone-ethyl mixture has been reported by previous authors, and the compatibility between them depends on the doses of the herbicides used in the mixture and on the species of weed under assessment (Werlang \& Silva, 2002). The increase in glyphosate efficacy by its association with herbicides sharing the mechanism of action of carfentrazone-ethyl has been observed in previous studies (Pereira \& Crabtree, 1986; Wells \& Appleby, 1992). The mixture of low doses of lactofen with glyphosate increased the accumulation of shikimate in the tissues of plants of Malva parviflora (Wells \& Appleby, 1992). 
These authors believe that lactofen promotes the entry of glyphosate into the cells. Pereira \& Crabtree (1986) reported an improvement in the absorption and translocation of glyphosate in plants of Cyperus esculentus after the addition of oxyfluorfen. The increase in the accumulation of shikimate and in the absorption, cell penetration, and translocation of glyphosate as a result of adding herbicides that inhibit PPO may explain the increased efficacy of the mixture glyphosate + carfentrazoneethyl under full sunlight conditions. Concenço et al. (2012) observed that the application of glyphosate alone was effective in the control of weeds even when it was performed at a later stage; however, carfentrazone-ethyl was only effective when applied after initial emergence. In the present study, the herbicides were applied whilst the plants were budding, which may be the reason for the poor control of M. atropurpureum observed when carfentrazone-ethyl was applied.

The effect of glyphosate, applied separately or in combination with carfentrazone-ethyl, was greater when the plants were cultivated under shade, with a mean reduction in dry mass of $80 \%$ and weed control of more than $90 \%$ relative to the control plant. The lower availability of light led to a reduction in the plants' dry mass and photosynthetic rate (Tables 1 and 2 ), which potentiated the effect of the herbicides (Figure 1). Shading reduces the amount of photosynthetically active radiation and compromises photochemical efficiency, the rate of electron transportation, and the activity of Rubisco (Li et al., 2010; Mu et al., 2010; Baldi et al., 2012). These changes are responsible for the decrease in photosynthetic rate and, consequently, for the lower accumulation of dry mass in the plants. An increase in the efficacy of Commelina benghalensis and Cyperus rotundus control by glyphosate under shading was also observed by Santos Júnior et al. (2013).

Application of the herbicides decreased the photosynthetic rate of M. atropurpureum at $2(\mathrm{p}<0.0001)$ and $6(\mathrm{p}<0.0001)$ DAA relative to the control plant, in all the environments tested (Table 2). At 2 DAA, the reduction in photosynthetic rates was greater in the shaded environments for the $1.440+0 \mathrm{~g} \mathrm{ha}^{-1}$ dose of glyphosate, and there was no difference between the environments at the other applied doses. At 6 DAA, the trend in photosynthetic rates was the same, with greater reductions in the shaded environments for the $0+40 \mathrm{~g} \mathrm{ha}^{-1}$ dose of carfentrazone-ethyl and the $1.440+0 \mathrm{~g} \mathrm{ha}^{-1}$ dose of glyphosate;

Table 2. Photosynthetic rates ( $\mu \mathrm{mol} \mathrm{m} \mathrm{m}^{-2} \mathrm{~s}^{-2}$ ) of Macroptilium atropurpureum treated with doses of glyphosate and/or carfentrazone-ethyl at 2 and 6 DAA, depending on the growth environment

\begin{tabular}{lcccc}
\hline \multirow{2}{*}{ Environment } & Doses of Glyphosate + Carfentrazone -ethyl ( $\mathbf{g}$ a.i. ha $\mathbf{~}^{-1}$ ) \\
\cline { 2 - 5 } & $\mathbf{0}+\mathbf{0}$ & $\mathbf{0}+\mathbf{4 0}$ & $\mathbf{1 . 4 4 0}+\mathbf{0}$ & $\mathbf{1 . 0 8 0}+\mathbf{3 0}$ \\
Full sunlight & $30.87 \mathrm{Aa}$ & $4.84 \mathrm{Ab}$ & $9.27 \mathrm{Ab}$ & $2.43 \mathrm{Ab}$ \\
$50 \%$ shading & $14.83 \mathrm{Ba}$ & $3.17 \mathrm{Ab}$ & $3.14 \mathrm{Bb}$ & $1.81 \mathrm{Ab}$ \\
$70 \%$ shading & $10.28 \mathrm{Ba}$ & $3.42 \mathrm{Ab}$ & $2.48 \mathrm{Bb}$ & $1.63 \mathrm{Ab}$ \\
\multicolumn{5}{c}{$\mathrm{CV}(\%): 34.2$} \\
\hline \multicolumn{5}{c}{$6 \mathrm{DAA}$} \\
Full sunlight & $29.28 \mathrm{Aa}$ & $19.26 \mathrm{Ab}$ & $12.97 \mathrm{Ab}$ & $2.41 \mathrm{Ac}$ \\
$50 \%$ shading & $15.00 \mathrm{Ba}$ & $3.85 \mathrm{Bb}$ & $0.63 \mathrm{Bb}$ & $0.90 \mathrm{Ab}$ \\
$70 \%$ shading & $12.55 \mathrm{Ba}$ & $2.46 \mathrm{Bb}$ & $0.74 \mathrm{Bb}$ & $1.72 \mathrm{Ab}$ \\
\hline \multicolumn{5}{c}{$\mathrm{CV}(\%): 34.8$} \\
\hline
\end{tabular}

Means followed by the same letters, uppercase in the column and lowercase in the row, do not differ by Tukey's test at 0.05 probability there were no differences for the $1.080+30 \mathrm{~g} \mathrm{ha}^{-1}$ dose of glyphosate + carfentrazone-ethyl.

Under full sunlight conditions, the combined use of the herbicides led to a greater reduction in the photosynthetic rates at 6 DAA. When glyphosate and carfentrazone-ethyl were used separately in this environment, the physiological recovery from herbicide treatment occurred at 6 DAA, compared to 2 DAA. The differences in photosynthetic rates explain the reduction in the dry mass of the plants under shading when the herbicides were applied.

Carfentrazone-ethyl acts by inhibiting a precursor of chlorophyll, protoporphyrinogen oxidase (Protox) (Dayan et al., 1997), which results in the accumulation of protoporphyrin IX (PpIX) in the cytosol (Jacobs \& Jacobs, 1993). In the presence of light, PpIX converts oxygen into singlet oxygen, which is responsible for the plant's death through membrane peroxidation (Jung et al., 2008). Fausey \& Renner (2001) reported an increase in the control of Amaranthus retroflexus by carfentrazone-ethyl of up to 15 times when the plants were exposed to radiation of $1.000 \mu \mathrm{mol} \mathrm{m} \mathrm{m}^{-2} \mathrm{~s}^{-2}$ after herbicide application, than when they were exposed to radiation of $4 \mu \mathrm{mol} \mathrm{m} \mathrm{m}^{-2} \mathrm{~s}^{-2}$. This indicates that radiation restriction, at the magnitudes tested in the present study, does not limit the formation of singlet oxygen or the efficacy of carfentrazoneethyl in shaded environments.

It has been found, however, that reduced radiation increases the synthesis of chlorophyll (Lopes et al., 2017), which may contribute to an increase in PpIX in plants that receive carfentrazone-ethyl. Thus, plants are more sensitive to the herbicide when grown under shade because of the increase in PpIX, which, in the presence of oxygen, promotes membrane peroxidation. These results are in line with those obtained by Thompson \& Nissen (2002), who assessed intoxication by sulfentrazone in soybean plants under $80 \%$ shade $\left(200 \mu \mathrm{mol} \mathrm{m}^{-2} \mathrm{~s}^{-2}\right)$.

The greater susceptibility to glyphosate of plants grown under shade may be associated with the greater absorption of the herbicide as a result of anatomical changes. These plants have a thinner epidermis with less cutin deposition (Skoss, 1955). Another mechanism that may contribute to the synergistic effect of shading on weed control by glyphosate is the reduction in nitrogen assimilation. Glyphosate phytotoxicity is caused by, among other factors, an increase in nitrate concentration in the tissues (Bellaloui et al., 2006). In this context, Neel et al. (2016) observed a similar effect of shading on nitrogen assimilation, with an increase in nitrate concentration in temperate climate grasses. Thus, plants under shading are more prone to accumulating nitrate and are, therefore, more sensitive to glyphosate.

Another factor that favors the action of herbicides in shaded environments is related to the greater probability of interception of sprayed chemicals by the plants because of the increased leaflet area in environments with light restriction (Figure 3).

Under full sunlight conditions, the leaflets of $M$. atropurpureum exhibited a mean area of $46.65 \mathrm{~cm}^{2}$, whereas under 50 and $70 \%$ shading the areas were 51.79 and 


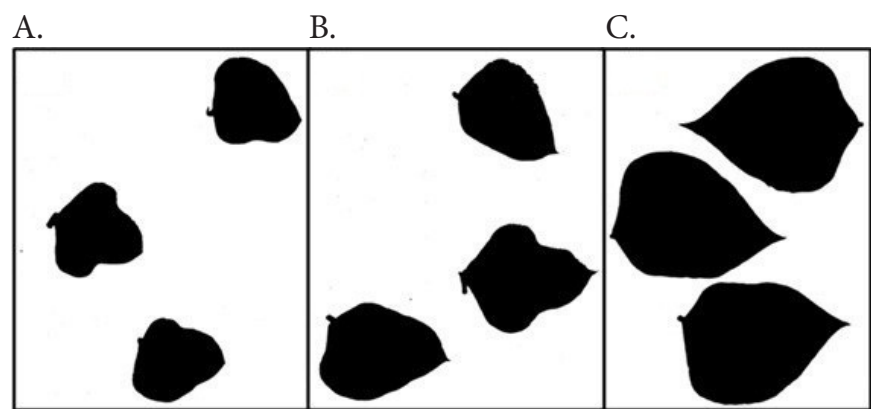

Figure 3. Area and shape of Macroptilium atropurpureum leaflets in different environments. (A) Under full sunlight conditions; (B) $50 \%$ shading; (C) $70 \%$ shading

$72.75 \mathrm{~cm}^{2}$, respectively (Figure 3). According to Li et al. (2010), leaf expansion is stimulated in plants under shading as a way of acclimatizing to the environment, to allow greater interception of incident radiation.

\section{Conclusions}

1. Macroptilium atropurpureum grown under full sunlight conditions showed a high tolerance to carfentrazone-ethyl and glyphosate. Mixing the two herbicides promoted improved results in the control of the plants under this condition.

2. Under shading, glyphosate applied alone or in combination with carfentrazone-ethyl was effective in controlling $M$. atropurpureum, which indicates a higher susceptibility of this species to the herbicides in environments with light restriction.

\section{ACKNowledgements}

The authors thank Fundação de Amparo à Pesquisa do Estado de Minas Gerais (FAPEMIG) for the study grant, Conselho Nacional de Desenvolvimento Científico e Tecnológico (CNPq) for providing a scholarship to the third author, and the Coordenação de Aperfeiçoamento de Pessoal de Nível Superior (CAPES) for providing a scholarship to the first author.

\section{Literature Cited}

ALAM - Associación Latinoamericana de Malezas. Recomendaciones sobre unificación de los sistemas de evaluación en ensayos de control de malezas. Associación Latinoamericana de Malezas, v.1, p.35-38, 1974.

Alvares, C. A.; Stape, J. L.; Sentelhas, P. C.; Moraes, G. de; Leonardo, J.; Sparovek, G. Köppen's climate classification map for Brazil. Meteorologische Zeitschrift, v.22, p.711-728, 2014. https:// doi.org/10.1127/0941-2948/2013/0507

Bagavathiannan, M.; Singh, V.; Govindasamy, P.; Abugho, S. B.; Liu, R. Impact of concurrent weed or herbicide stress with other biotic and abiotic stressors on crop production. In: Kumar, M. S. (ed.). Plant tolerance to individual and concurrent stresses. New Delhi: Springer, 2017. Chap.3, p.33-45. https://doi.org/10.1007/978-81-322-3706-8_3

Baldi, P.; Muthuchelian, K.; Porta, N. L. Leaf plasticity to light intensity in Italian cypress (Cupressus sempervirens L.): Adaptability of a Mediterranean conifer cultivated in the Alps. Journal of Photochemistry and Photobiology B: Biology, v.117, p.61-69, 2012. https://doi.org/10.1016/j.jphotobiol.2012.09.006
Bellaloui, N.; Reddy, K. N.; Zablotowicz, R. M.; Mengistu, A. Simulated glyphosate drift influences nitrate assimilation and nitrogen fixation in non-glyphosate-resistant soybean. Journal of Agricultural and Food Chemistry, v.54, p.3357-3364, 2006. https://doi.org/10.1021/jf0531981

Besançon, T.; Heiniger, R.; Weisz, R.; Everman, W.; Weed response to agronomic practices and herbicide strategies in grain sorghum. Agronomy Journal, v.109, p.1642-1650, 2017. https://doi. org/10.2134/agronj2016.06.0363

Braz, G. B. P.; Oliveira Júnior, R. S.; Constantin, J.; Oliveira Neto, A. M.; Dan, H. A.; Guerra, N.; Osipe, J. B.; Takano, H. K. Alternativas para o controle de soja $\mathrm{RR}^{\oplus}$ voluntária na cultura do algodoeiro. Bioscience Journal, v.29, p.360-369, 2013.

Cantarutti, R. B.; Barros, N. F.; Emilia, H.; Martinez, P.; Novais, R. F. Avaliação da fertilidade do solo e recomendação de fertilizantes. In: Novais, R. F.; Alvarez V., V. H.; Barros, N. F.; Fontes, R. L.; Cantarutti, R. B.; Neves, J. C. L. (eds.). Fertilidade do solo. Viçosa: Sociedade Brasileira de Ciência do Solo, 2007. Cap.13, p.769-850.

Cieslik, L. F.; Vidal, R. A.; Trezzi, M. M. Fatores ambientais que afetam a eficácia de herbicidas inibidores da accase: Revisão. Planta Daninha, v.31, p.483-489, 2013. https://doi.org/10.1590/S010083582013000200026

Concenço, G.; Andres, A.; Galon, L.; Pontes, C. S.; Correia, V. Controle de Macroptilium lathyroides com herbicidas aplicados em pré e pós emergência. Revista Brasileira de Herbicidas, v.11, p.11-23, 2012. https://doi.org/10.7824/rbh.v11i1.144

Dayan, F. E.; Weete, J. D.; Duke, S. O.; Hancock, H. G. Soybean (Glycine max) cultivar differences in response to sulfentrazone. Weed Science, v.45, p.634-641, 1997.

Fausey, J. C.; Renner, K. A. Environmental effects on CGA-248757 and flumiclorac efficacy/soybean tolerance. Weed Science, v.49, p.668674, 2001. https://doi.org/10.1614/0043-1745(2001)049[0668:EE OCAF]2.0.CO;2

Fonseca, W. L.; Sousa, T. O.; Santos, A. S.; Oliveira, J. B. S.; Pacheco, L. P.; Medeiros, L. C.; Zuffo, A. M.; Almeida, F. A. Influence of different cover crops on the emergence and development of Digitaria horizontalis. Australian Journal of Crop Science, v.10, p.1244-1248, 2016. https://doi.org/10.21475/ajcs.2016.10.09. p7624

Jacobs, J. M.; Jacobs, N. J. Porphyrin accumulation and export by isolated barley (Hordeum vulgare) plastid. Plant Physiology, v.101 p.1181-1187, 1993. https://doi.org/10.1104/pp.101.4.1181

Jung, H. I.; Kuk, Y. I.; Back, K.; Burgos, N. R. Resistance pattern and antioxidant enzyme profiles of protoporphyrinogen oxidase (PROTOX) inhibitor-resistant transgenic rice. Pesticide Biochemistry and Physiology, v.91, p.53-65, 2008. https:/doi. org/10.1016/j.pestbp.2008.01.005

Kucharski, M.; Kieloch, R. Evaluation of the possibility of tribenuron methyl dose limitation in relations to selected abiotic factors and growth stage of weeds. Progress in Plant Protection, v.55, p.461-465, 2015.

Li, H. W.; Jiang, D.; Wollenweber, B.; Dai, T. B.; Cao, W. X. Effects of shading on morphology, physiology and grain yield of winter wheat. European Journal of Agronomy, v.33, p.267-275, 2010. https://doi.org/10.1016/j.eja.2010.07.002 
Lopes, C. M.; Paciullo, D. S. C.; Araújo, S. A. C.; Gomide, C. A. M.; Morenz, M. J. F.; Villela, S. D. J. Herbage mass, morphological composition and nutritive value of signalgrass, submitted to shading and fertilization levels. Arquivo Brasileiro de Medicina Veterinária e Zootecnia, v.69, p.225-233, 2017. https://doi. org/10.1590/1678-4162-9201

Lorenzi, H. Plantas daninhas do Brasil: Terrestres, aquáticas, parasitas, tóxicas e medicinais. 4.ed. Nova Odessa: Instituto Plantarum, 2008. 672p.

Matzenbacher, F. O.; Vidal, R. A.; Merotto, J. R. A.; Trezzi, M. M. Environmental and physiological factors that affect the efficacy of herbicides that inhibit the enzyme protoporphyrinogen oxidase: A literature review. Planta Daninha, v.32, p.457-463, 2014. https:// doi.org/10.1590/S0100-83582014000200024

Mu, H.; Jiang, D.; Wollenweber, B.; Dai, T.; Jing, Q.; Cao, W. Longterm low radiation decreases leaf photosynthesis, photochemical efficiency and grain yield in winter wheat. Journal of Agronomy Crop Science, v.196, p.38-47, 2010. https://doi.org/10.1111/j.1439037X.2009.00394.x

Neel, J. P. S.; Felton, E. E. P.; Singh, S.; Sexton, A. J.; Belesky, D. P. Open pasture, silvopasture and sward herbage maturity effects on nutritive value and fermentation characteristics of cool-season pasture. Grass and Forage Science, v.71, p.185-195, 2016. https:// doi.org/10.1111/gfs.12172

Pereira, W.; Crabtree, G. Absorption, translocation, and toxicity of glyphosate and oxyfluorfen in yellow nuts edge (Cyprus esculentus L.). Weed Science, v.34, p.923-929, 1986.

Rocha, D. C.; Rodella, R. A.; Martins, D.; Maciel, C. D. G. Efeito de herbicidas sobre quatro espécies de trapoeraba. Planta Daninha, v.25, p.359-364, 2007. https://doi.org/10.1590/S010083582007000200016

Santos, F. J.; Pitombeira, J. B.; Pinho, J. L. N.; Melo, F. I. O. Controle químico de plantas daninhas na cultura do arroz irrigado no Estado do Ceará. Planta Daninha, v.18, p.29-37, 2000. https:// doi.org/10.1590/S0100-83582000000100003
Santos, L. D. T.; Cardoso Filho, O.; Santos Júnior, A.; Santos, B. F. S.; Felix, R. C.; Leite, F. P. Floristic and structural variation of weeds in eucalyptus plantations as influenced by relief and time of year. Planta Daninha, v.31, p.491-499, 2013. https://doi.org/10.1590/ S0100-83582013000300001

Santos, S. A.; Santos, L. D. T.; Santos, B. F. S.; Tanaka, F. A. O.; Silva, L. F.; Santos Júnior, A. Influence of shading on the leaf morphoanatomy and tolerance to glyphosate in Commelina benghalensis L. and Cyperus rotundus L. Australian Journal of Crop Science, v.9, p.135-142, 2015.

Santos Júnior, A.; Santos, L. D. T.; Costa, G. A.; Barbosa, E. A.; Leite, G. L. D.; Machado, V. D.; Cruz, L. R. Manejo de tiririca e trapoeraba com glyphosate em ambientes sombreados. Planta Daninha, v.31, p.213-221, 2013. https://doi.org/10.1590/S010083582013000100023

SAS - SAS Institute Inc. Cary: SAS Institute Inc., 2002.

Skerman, P. J. Tropical forage legumes. 2.ed. Rome: Plant Production Series/FAO, 1977. 609p.

Skoss, J. D. Structure and composition of plant cuticle inrelation to environmental factors and permeability. Botanical Gazette, v.117, p.55-72, 1955. https://doi.org/10.1086/335891

Thompson, W. M.; Nissen, S. J. Influence of shade and irrigation on the response of corn (Zea mays), soybean (Glycine max), and wheat (Triticum aestivum) to carfentrazone-ethyl. Weed Technology, v.16, p.314-318, 2002. https://doi.org/10.1614/0890-037X(2002 )016[0314:IOSAIO]2.0.CO;2

Wells, B. H.; Appleby, A. P. Lactofen increases glyphosate-simulated shikimate production in little mallow (Malva parviflora). Weed Science, v.40, p.171-173, 1992. https://doi.org/10.1017/ S0043174500057167

Werlang, R. C.; Silva, A. A. Interação de glyphosate com carfentrazoneethyl. Planta Daninha, v.20, p.93-102, 2002. https://doi. org/10.1590/S0100-83582002000100013 